\title{
Review
}

\section{Excluded within: The [un]intelligibility of radical political actors}

\author{
Sina Kramer \\ New York, Oxford, 2017, ix + 241pp., \\ ISBN: 978-0190625986
}

Contemporary Political Theory (2019) 18, S240-S242. https://doi.org/10.1057/s41296018-0245-0; published online 9 August 2018

Sina Kramer has written an excellent book about the epistemological and political invisibility of radical political actors. The question that animates this project is an important one: 'If what appears as intelligible to us has been so determined by the terms set out by means of constitutive exclusion, then how can we see, hear, or recognize anything beyond or outside of those terms?' (p. 104). For the author, the answer is simple. We need new terms of intelligibility so we can re-learn how to see, hear, and recognize the world. This will allow us to see groups positioned as internally excluded.' To such an end, the author engages a wide range of literatures including critical, radical democratic, feminist, queer, and critical race theories. The goal is to trouble a 'normal' way of being in and seeing the world. Normal or hegemonic modes of being and seeing have disastrous ethical and political consequences. The author thus calls for resistance and subversion against epistemological and political blindness in a politically charged context where radical forms of protest and counter-protest constitute the new political status quo. Protest and resistance are not enough, though. Kramer shows us how to rethink and recreate structures of cognition in order to open new conditions of political possibility for our world. For the author, our political horizons need to be 'determined democratically' not via an epistemology of ignorance (p. 85). The author avoids the dead ends of pessimism, despair, and left melancholy and embraces a 'pluralist political ontology as a way of doing justice to our multiple exclusions by means of illuminating our multiple constitutions' (p. 24).

The argument that runs throughout the book is a serious one that deserves our attention. Dominant groups, the ruling class, and those complicit with this nightmare of 'internal exclusion' frequently proclaim that everything is fine for everyone. They refuse to see how their privilege is intertwined with domination and injustice. If political change can no longer be denied as a result of a shift in public opinion or mass uprisings, then the ruling class identifies token stand-ins that represent nonthreatening modes of symbolic change. This is why Rosa Parks, whom Kramer calls 'a reified political object' (p. 5), is embraced via 'white-

(c) 2018 Springer Nature Limited. 1470-8914 Contemporary Political Theory Vol. 18, S4, S240-S242 
washing,' and the more threatening angry radical activist Claudette Colvin is ignored and tossed into the garbage heap of history. Politics is conceived of by Kramer as the fight against 'producing lives that are unintelligible' (p. 15) and perpetuating the inequalities that go along with this. A better world is possible. However, we need to be attuned to fake gestures that cloak injustice with the regalia of progress.

To this end, Kramer 'offers an analysis of the concept of constitutive exclusion and the contestations of concrete exclusions to better articulate how we know what counts as a political action and who counts as a political agent' (p. 5). The book thus stages a battle between the intelligible and the unintelligible and contains a much-needed utopian dimension. This gives the reader hope of a redeemed world. The ultimate goal, as Kramer puts it, is to 'redeem those shards of radical potential buried in the sedimentation of the political present pushing us toward a reconstitution of the political field and the terms of political agency it animates' (p. 12). The utopian moment is the chance for the 'reconstitution of the political body on new terms' (p. 7). Kramer continues: 'Any closed system contains the kernel of this utopic speculative moment within it' (p. 107). A good critical theorist, Kramer goes to what 'has been thrown away, degraded, and abjected' (p. 110) as a way to grasp and transform the political moment.

If Kramer wants to reconstitute the political body on better, meaning more equitable terms, it might be necessary for the author to engage not only the radical and critical literatures that animate this text but at least some of the more traditional approaches to the study of politics. This could serve to demonstrate how more traditional approaches to the study of politics (e.g., ones based on the celebration of liberal democracy; proclamations of the end of history and the triumph of capitalism) have not only prevented us from seeing what is right in front of us, but are complicit with the current phase of authoritarian neoliberal hell. It might also be helpful if the author distinguished in greater detail the implications of this project (e.g., the need to contest constitutive exclusion) from other strands of critically oriented research that also appeal to contestation.

Nevertheless, Kramer brilliantly navigates a wide range of perspectives and approaches to the study of politics. For example, the notoriously challenging work of Hegel, Derrida and Adorno is presented with great clarity, analyzing how what contradicts 'the whole system is nevertheless necessary to that system' (p. 69). Then, Kramer retells the story of the LA riots/uprising as an essentially political uprising, not an episode of criminal lawlessness. Kramer thus brings sky-high theory into relation with street politics and opens a new legacy and trajectory for the Los Angeles uprising. This event may have taken place in 1992, but it continues to haunt Los Angeles and other world cities, the places where poor people of color are over-policed and pounded into submission as the dominant strategy of social cohesion.

(c) 2018 Springer Nature Limited. 1470-8914 Contemporary Political Theory Vol. 18, S4, S240-S242 S241 
The point of Kramer's reflections is to identify the current command-and-control strategies and re-politicize 'the exclusions by which we define ourselves' (p. 85). If exclusions are inevitable, then they at least should be 'determined democratically rather than by means of a disavowal that props up an epistemology of ignorance' (p. 85). If injustice still results from decisions determined democratically then they are arguably less bad, because at least we know and are being honest about what we are doing. For this reason, perhaps these injustices will be easier to stomach. Kramer nonetheless insists that thought and struggle can create a better world where 'things may yet turn out otherwise' (p. 121).

Is there a future beyond constitutive exclusion even if it is determined democratically and via radical contestation, or does the critique of constitutive exclusion name a perpetually unfinished project that calls for interminable struggle? A direct answer to this question would serve to further clarify Kramer's argument and the significance of it. Perhaps the answer to this question is left unanswered because it will be addressed in a future project. Nonetheless, Kramer has written a compelling and provocative book that will be of keen interest to scholar-activists and progressive thinkers who would like to expand their critical mindset and perhaps see something that they have not been able to notice thus far, namely, how everyone's future is intertwined with the future of the 'internally excluded.'

William W. Sokoloff University of Texas Rio Grande Valley, Edinburg, TX 78539, USA william.sokoloff@utrgv.edu 